\title{
Naturalization and invasion of alien plants in Puerto Rico and the Virgin Islands
}

\author{
Julissa Rojas-Sandoval • Pedro Acevedo-Rodríguez
}

Received: 2 January 2014/ Accepted: 3 May 2014/Published online: 11 May 2014

(C) The Author(s) 2014. This article is published with open access at Springerlink.com

\begin{abstract}
A fundamental goal in invasion ecology is to identify and understand the factors explaining why some alien species become invasive when others fail. In this study we gathered data on taxonomy, invasive status, invasion history, geographic distribution, and biological and ecological traits of 1,032 alien plant species occurring on different habitats in Puerto Rico and the Virgin Islands. These data were used to evaluate the relative importance of habitat and species attributes in influencing the likelihood of alien plants to become naturalized and subsequently invasive on these islands. Our results showed that alien species were more likely to become naturalized if they grow in semi-natural habitats, have large native distribution ranges, long residence time, were introduced for horticulture and have mixed breeding systems. On the other hand, naturalized species were more likely to become invasive if they were introduced for horticulture, behave as weeds, have tolerance to different climatic life-zones, thrive in ruderal habitats, have mixed breeding systems with hermaphroditic flowers, reproduce vegetatively and produce small seeds.
\end{abstract}

Electronic supplementary material The online version of this article (doi:10.1007/s10530-014-0712-3) contains supplementary material, which is available to authorized users.

J. Rojas-Sandoval $(\bowtie) \cdot$ P. Acevedo-Rodríguez Department of Botany, National Museum of Natural History, MRC-166 Smithsonian Institution, P.O. Box 37012, Washington, DC 20013, USA

e-mail: julirs07@gmail.com
Whereas some of these parameters were important for both transitions, others were important for either naturalization or invasion. Overall, our results emphasize the importance of studying different stages of the invasion process in order to understand the mechanisms explaining successful invasions rather than baseline approaches of simply comparing invasive with natives or noninvasive alien species. Understanding the process by which alien species become naturalized or invasive could provide a more objective and accurate approach for managing and predicting biological invasions.

Keywords Alien flora - Biological invasions . Caribbean Islands · Invasive plants · Invasive status · Invasibility · Puerto Rican archipelago

\section{Introduction}

Biological invasions are considered one of the major threats to the conservation of biodiversity (Mack et al. 2000; Levine et al. 2003; D'Antonio et al. 2004). At a global scale, plants are among the most widespread invasive organisms as they are frequently introduced for agriculture, agroforestry and ornamental purposes (Daehler 2003; D'Antonio et al. 2004; Pyšek et al. 2012). After introduction, the progression of alien plants along the entire introduction-naturalizationinvasion continuum, involves the interplay of different biotic and abiotic factors (Richardson et al. 2000; 
Catford et al. 2009). Factors contributing to the successful invasion of alien plants include geographical location, climate and socio-economic conditions (i.e., human density and degree of urban development) and species traits influencing the ability of alien plants to survive, reproduce, disperse and interact with resident species (Higgins and Richardson 1999; Davis et al. 2000; Rejmánek 2000; Pyšek and Richardson 2010; Richardson and Pyšek 2012).

Worldwide, insular biomes are considered more vulnerable to invasions than continental ecosystems as they host higher numbers and densities of alien species than equivalent mainland communities (D'Antonio and Dudley 1995; Simberloff 1995; Rejmánek 1996; Simberloff 2000; Denslow 2003; Denslow et al. 2009). For example, the number of naturalized alien plants recorded on oceanic islands is almost twice the number of those recorded in similar sized patches on mainland with approximately the same number of native species (Sax et al. 2002). The high rates of "invasibility" and naturalization of alien plants on islands have been traditionally explained by inherent features of islands such as their geographical and historical isolation. Accordingly, insular ecosystems are considered areas with disharmonic and unsaturated floras with poorly competitive species, low pest pressures and missing important functional groups which are factors that would provide few barriers to the establishment and naturalization of alien plants (Rejmánek 1996; Mack et al. 2000). However, these assumptions are rarely supported by empirical data, leading other studies to postulate that small territories, reduced extension of habitats and small population sizes could be responsible for the high invasibility of islands (Simberloff 2000 and references therein).

Puerto Rico and the Virgin Islands (hereafter PRVI) are located in the Caribbean region, one of the most important biodiversity hotspots in the world (Myers et al. 2000). Caribbean Islands are considered areas with high priority for conservation due to their biological richness, high levels of endemism ( $>70 \%$ for seed plants; Acevedo-Rodríguez and Strong 2012) and high levels of anthropogenic disturbances (Mittermeier et al. 1998; Myers et al. 2000). Despite their biodiversity relevance, during the last century PRVI have been subjected to extensive deforestation and massive degradation of their natural environments through agricultural activities (i.e., sugarcane and coffee plantations; Maunder et al. 2008). By the 1940s, Puerto Rico had lost more than $90 \%$ of its original forest cover and only about $1 \%$ of the original forest remained unmodified (Lugo 2004). A shift in the economy from agriculture to manufacturing after the 1950s led to the abandonment of agricultural lands and to an increase in secondary forest cover. By the 1990s more than $30 \%$ of the island was covered by secondary forest representing the largest event of forest recovery recorded anywhere in the world (Aide et al. 1995; Franco et al. 1997; Lugo 2004). Similar patterns of environmental degradations and subsequent abandonment of agricultural fields have also been described for the Virgin Islands (AcevedoRodríguez 1996). Overall, high population densities (island mean $=340$ people per $\mathrm{km}^{2}$ ), high urbanization rates and accelerated socio-economic changes have resulted in major alterations in the landscape and biodiversity on PRVI (López del Mar et al. 2001; Lugo 2004).

Although PRVI have one of the best available data on alien flora within the Caribbean region (Liogier and Martorell 1982; Acevedo-Rodríguez and Strong 2012), a compressive inventory of alien plants as well as an assessment of the factors influencing invasiveness and invasibility are still lacking for these islands. Studies using checklists and databases to categorize alien species into objective defined groups such as casual, naturalized and invasive are extremely valuable for understanding invasion processes (Pyšek et al. 2004; Cadotte et al. 2006). Such comprehensive databases provide the necessary baseline information and are essential tools for the management of biological invasions through early detection and rapid response (Khuroo et al. 2012). Within this context, the main goals of this work were to: (1) generate a comprehensive database for the alien flora of PRVI containing taxonomical information, residence time, invasion history, invasion status, life-cycle traits and habitat preferences, and (2) use all this information to identify and evaluate the factors influencing the likelihood of naturalization and the invasion success of alien plants in PRVI. We expect that understanding why some alien species become naturalized and invasive while others fail to do so would be crucial in designing appropriate management and conservation strategies to control and mitigate the impact of invasive plants on these islands. 


\section{Methods}

Study site

The study area includes 15 islands located in the Puerto Rican archipelago and integrates the political units of Puerto Rico (Puerto Rico, Culebra, Vieques, Caja de Muerto, Icacos, Piñeros, Mona, and Desecheo), the American Virgin Islands (St. Croix, St. John and St. Thomas) and the British Virgin Islands (Anegada, Tortola, Josh Van-Dyke and Virgin Gorda). Together, these islands cover an area of about 960,330 ha (Heatwole et al. 1981). The majority of the islands within the Virgin cluster (except St. Croix) lost their connection with Puerto Rico and among themselves only about $8,000-10,000$ years ago as a result of rising sea levels. Climate on PRVI is tropical and predominantly maritime with slight seasonal variation in temperature along the year. Rainfall is highly seasonal with a dry season taking place between December and April followed by a wet season between May and November coinciding with the Atlantic hurricane season (Daly et al. 2003).

Database of alien plants in Puerto Rico and Virgin Islands

The dataset presented here includes all alien plant species recorded for PRVI in Acevedo-Rodríguez and Strong (2012), specimens at the U.S. National Herbarium, and botanical surveys, original articles and checklists published since 1535 (Table 1). Using this information, we created a preliminary list encompassing 1,147 alien species. After removing species with unreliable records, hybrids and species that occurs exclusively in human-made habitats (i.e., croplands and gardens), the list was reduced to 1,032 species. A total of 22 parameters including information on taxonomy, geographical distribution, invasion history, and biological and ecological species attributes were evaluated for each species. All parameter definitions are given in Table 1. To facilitate comparison with databases on alien plants from other regions, we followed the parameters and definitions suggested by Richardson et al. (2000) and Pyšek et al. (2004).
Parameters determining naturalization and invasion success

We used a generalized linear modeling approach (logistic regression; binomial GLM with logit link) to identify and evaluate the parameters influencing the likelihood of an alien plant to become naturalized and invasive in PRVI. In a first analysis we determined the parameters distinguishing casual and naturalized species, while in a second analysis we determined the parameters distinguishing naturalized and invasive species (Richardson and Pyšek 2012). In the first analysis, species scored 1 if they were naturalized or 0 if they were casuals. In the second analysis species scored 1 if they were invasive or 0 if they were naturalized (Milbau and Stout 2008). To fulfill logistic regression assumptions, parameters were recoded as dichotomous variables. To avoid problems of multicollinearity, correlated parameters (i.e., perennial life-spam and vegetative propagation) were not included together in the analyses. Because logistic regression assumes a non-linear model, full datasets and large number of observations per each variable included in the model are necessary to achieve accurate results (Menard 2002). Therefore, we used only those parameters with records for at least 600 species (Table 2). In addition, because we had a large set of parameters (potential explanatory variables) for each analysis, we searched for the best-fit (minimal) model that includes only significant variables and interactions. The best-fit models were selected using the Akaike Information Criteria (Menard 2002; Milbau and Stout 2008). Once models were obtained, we checked for the presence of significant interactions between explanatory variables. Finally, odds ratios were calculated for significant variables as the ratio of the probability that an alien species were successful in the naturalization or invasion process to the probability of failure. Odds ratios can take values of from 0 to infinity, whereas values $<1$ represent a decrease in success probability and values $>1$ represent an increase in success probability per unit increase of the variable. Greater departure from 1 indicates a stronger relationship between the variable and the response (Milbau and Stout 2008). 
Table 1 Description of the parameters included in the database of alien plant species for Puerto Rico and the Virgin Islands

\begin{tabular}{ll}
\hline Parameters & Description \\
\hline $\begin{array}{l}\text { Species identity } \\
\text { Genus }\end{array}$ & $\begin{array}{l}\text { According to Acevedo-Rodríguez and Strong (2012) } \\
\text { Species }\end{array}$ \\
$\begin{array}{l}\text { Family } \\
\text { Anvasion history } \\
\text { Invasion status }\end{array}$ & $\begin{array}{l}\text { According to Acevedo-Rodríguez and Strong (2012) } \\
\text { Casual (alien plants that may flourish and reproduce occasionally outside cultivation, do not form self- } \\
\text { replacing populations, and rely on repeated introductions for their persistence), naturalized (alien } \\
\text { plants that sustain self-replacing populations for at least 10 years without direct intervention by } \\
\text { people and are capable of independent growth) and invasive (naturalized plants producing } \\
\text { reproductive offspring, often in very large numbers, at considerable distances from the parent plants, } \\
\text { with the potential to spread over a large area; Richardson et al. 2000) }\end{array}$
\end{tabular}

Year of introduction

Abundance

Type of introduction

Planting purposes

Economic weed
Based on the first record of the species in the wild (Pyšek et al. 2004)

Rare, occasional, frequent, dominant

Intentional (species deliberately planted in the wild or in human-made habitats), unintentional (contaminants, stowaways, and accidental introductions), escaped (species introduced intentionally and later escaped from cultivation). Modified from Pyšek et al. (2011)

E.g., ornamental, food, forage, agroforestry, medicinal, timber tree

Yes/No; is the species a weed (plants growing in sites where they are not wanted and which have detectable economic impact; Richardson et al. 2000; Pyšek et al. 2004) in agriculture, pastures, nurseries (Más and Lugo-Torres 2013)

Habitat and geographic distribution

Native range

Island occurrence

Habitat strategy

Invaded life zones
Geographic distribution where native. Modified from Weber (2003) as: Africa, Asia, Europe, Australia-Pacific, North America, Central America, South America, West Indies

Species occurrence in PR = only in Puerto Rico, VI = only in the Virgin Islands, PRVI = both

Yes/No; species occurrence in agricultural (traditional agriculture lands), ruderal (human-made habitats, excluding agricultural), semi-natural (low to medium disturbed areas, including secondary forest), and mature forest (very low disturbed areas). Modified from Lloret et al. (2005)

Yes/No; species occurrence in the life zones described for Puerto Rico and the Virgin Islands. Life zones according to Ewel and Whitmore (1973): dry forest, moist forest, wet forest, rain forest, lower montane wet forest, lower montane rain forest

\section{Biological and ecological traits}

Life-form

Grass, herb, aquatic herb, shrub, tree, vine

Life-span

Reproduction type

Annual, biennial, perennial

Breeding system

Hermaphrodite, monoecious, dioecious, gynomonoecious, andromonoecious, polygamous

Selfing (species rely almost exclusively on apomixis or autonomous self-pollination) outcrossing (species rely almost exclusively on cross-pollination), mixed (selfing + outcrossing)

Pollination type

Animal, wind, water, unspecialized

Fruit type

Achene, berry, capsule, caryopsis, cone, drupe, dry, fleshy, follicle, legume, nut, nutlet, samara, syncarp, utricle

Seed size

Five size categories: $1=$ very small $(<1 \mathrm{~mm}), 2=$ small $(1-2 \mathrm{~mm}), 3=$ medium $(2-5 \mathrm{~mm})$, $4=$ large $(5-10 \mathrm{~mm}), 5=$ very large $(>10 \mathrm{~mm})$

Dispersal mode Animal, humans, wind, water, unspecialized

Vegetative propagation

Information for each species was obtained from herbarium collections and the literature

Main sources of literature consulted: Fernández de Oviedo (1535), Eggers (1876, 1879), Bello (1881, 1883), Stahl (1883-1888), Urban (1898-1928), Britton and Wilson (1923, 1926), García-Molinari (1952), Liogier and Martorell (1982), Liogier (1985-1997), Kairo et al. (2003), Acevedo-Rodríguez (2005), Acevedo-Rodríguez and Strong (2005), Axelrod (2011), Acevedo-Rodríguez and Strong (2012), Más and Lugo-Torres (2013), PLANTS Database (USDA-NRCS: http://plants.usda.gov), Germplasm Resources Information Network (USDA-ARS-GRIN: http://www.ars-grin.gov/) 
Table 2 Parameters used in the binomial GLM logistic regression model to identify parameters explaining the successful transitions from casual to naturalized and from naturalized to invasive for alien plants in Puerto Rico and the Virgin Islands

\begin{tabular}{|c|c|c|c|}
\hline Parameters & Variable & Description & Records \\
\hline \multicolumn{4}{|l|}{ Invasion history } \\
\hline Year of introduction & Continuous & First record of the species in the wild & 612 \\
\hline Type of introduction (horticulture) & Dichotomous (yes, no) & $\begin{array}{l}\text { Introduced intentionally for horticulture } \\
\text { (i.e., fruit-trees, ornamentals, and } \\
\text { ground cover species) }\end{array}$ & 635 \\
\hline Economic weed & Dichotomous (yes, no) & Weed in agriculture, pastures, nurseries, etc. & 642 \\
\hline \multicolumn{4}{|l|}{ Habitat and geographic distribution } \\
\hline Native range & Continuous & $\begin{array}{l}\text { Number of geographic areas (continents) } \\
\text { where native }\end{array}$ & 642 \\
\hline Habitat strategy (ruderal) & Dichotomous (yes, no) & Occurrence in ruderal habitats & 642 \\
\hline Habitat strategy (semi-natural) ${ }^{\mathrm{a}}$ & Dichotomous (yes, no) & Occurrence in semi-natural habitats & 642 \\
\hline Life zones incidence & Continuous & Number of life zones where the species occurs & 642 \\
\hline \multicolumn{4}{|l|}{ Biological and ecological traits } \\
\hline Hermaphrodite & Dichotomous (yes, no) & Presence of hermaphrodite flowers & \\
\hline Breeding system (mixed) & Dichotomous (yes, no) & $\begin{array}{l}\text { Species with capability for self-pollination } \\
\quad+\text { outcrossing }\end{array}$ & 610 \\
\hline Pollination type (wind) & Dichotomous (yes, no) & Flowers pollinated by wind & 620 \\
\hline Pollination type (animal) ${ }^{\mathrm{a}}$ & Dichotomous (yes, no) & Flowers pollinated by animals & 620 \\
\hline Seed size & Dichotomous (yes, no) & Presence of seeds greater than $5 \mathrm{~mm}$ & 640 \\
\hline Dispersion (wind) & Dichotomous (yes, no) & Seeds dispersed by wind & 625 \\
\hline Dispersion (animal) ${ }^{\mathrm{a}}$ & Dichotomous (yes, no) & Seeds dispersed by animals & 620 \\
\hline Vegetative propagation & Dichotomous (yes, no) & Presence of clonal and vegetative growth & 628 \\
\hline
\end{tabular}

a Variables used modeling the transition from casual to naturalized

\section{Results}

Species richness and abundance

The alien flora in PRVI consists of 1,032 species, represented by 117 families and 581 genera, and contributes to $32.3 \%$ of the total flora found on these islands. Regarding the invasion status, we classified 392 species (38 \%) as casuals, 463 species (44.9\%) as naturalized and the remaining 177 species $(17.2 \%)$ as invasive (Fig. S1 in ESM). Although the number of casual, naturalized and invasive species occurring only in Puerto Rico are considerably higher than those occurring only in the Virgin Islands, both archipelagos shared 96 casuals (24.5\% of all casuals), 224 naturalized (48.4\% of all naturalized) and 122 invasive species $(68.9 \%$ of all invasive; Fig. S2 in ESM).

The families with the largest number of alien species in PRVI are Fabaceae (131 species representing
$12.7 \%$ of all alien plant species in PRVI), Poaceae (119 species representing $11.5 \%$ ), and Asteraceae (54 species representing $5.2 \%$; Fig. 1a), all three contributing to $29.4 \%$ of all alien species. A total of 32 families $(27.4 \%)$ were represented by only one species (Table S1 in ESM). The genera Citrus (12 species), Digitaria (11 species), Solanum (10 species), Bambusa (10 species) and Hibiscus (10 species) were the most diverse, while 386 genera $(63.3 \%)$ were only represented by one species. We also found that 55 out of the 117 families of alien plants included at least one invasive species. The family with the highest number of invasive species was Poaceae ( 35 species) followed by Fabaceae ( 29 species), Asteraceae ( 9 species) and Acanthaceae (8 species; Fig. 1a). Among the invasive species listed for PRVI, Antigonon leptopus, Epipremnum pinnatum, Leucaena leucocephala, Megathyrsus maximus, Oeceoclades maculata, Pueraria phaseoloides, Spathodea campanulata, Syngonium podophyllum, Syzygium jambos, Thunbergia alata and Urochloa 
Fig. 1 Classification of the alien flora of Puerto Rico and the Virgin Islands considering: a the 15 most numerous families ranked according to the number of alien species, b life-forms and $\mathbf{c}$ life-span categories
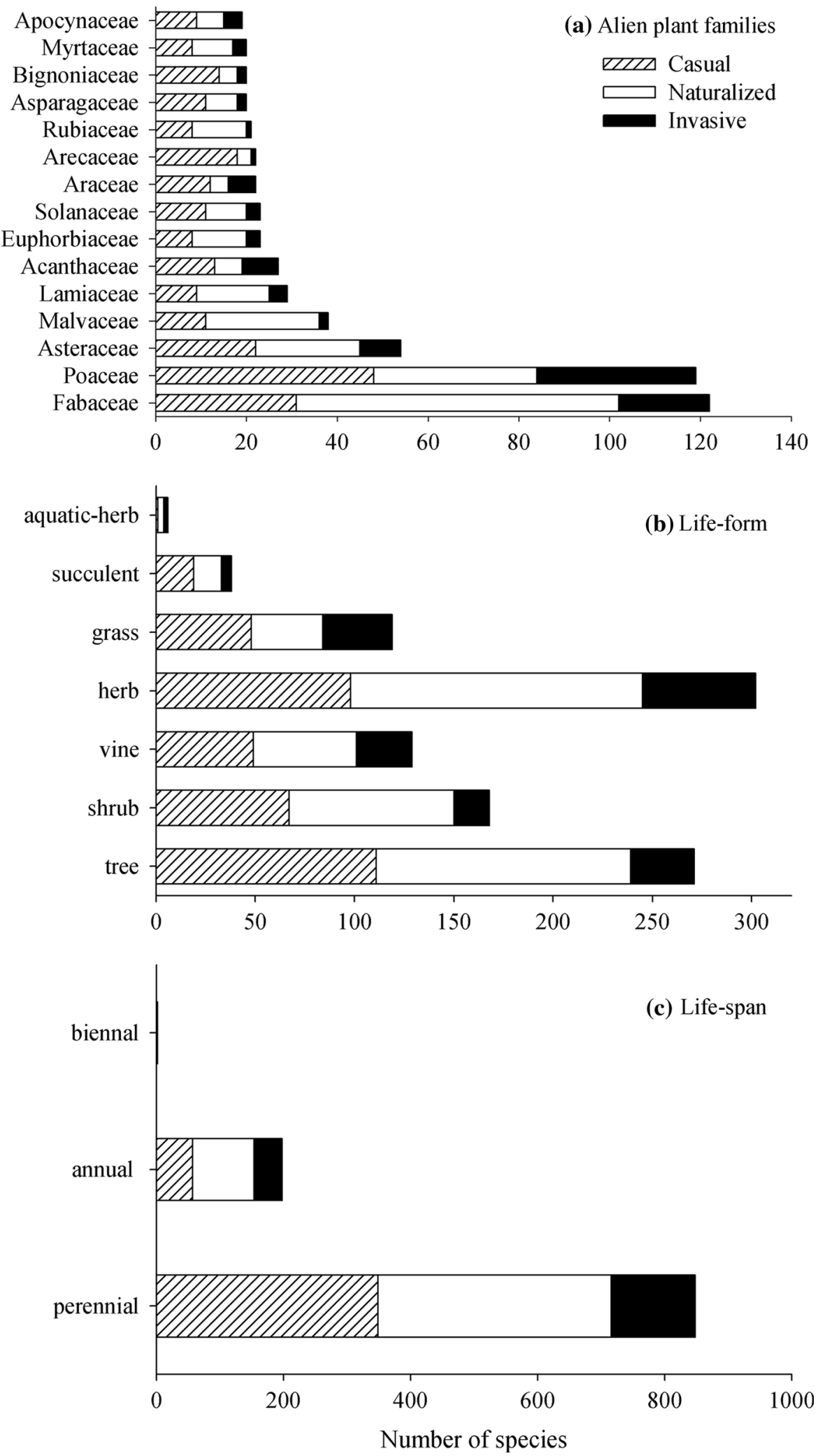
mutica are some of the most conspicuous in terms of abundance (Table S2 in ESM).

\section{Life-forms}

The alien flora of PRVI is quite diverse in terms of life forms with $29.3 \%$ of them being herbs, $26.3 \%$ trees, $16.2 \%$ shrubs, $12.5 \%$ vines, $11.5 \%$ grasses and $4.3 \%$ succulents or aquatic herbs (Fig. 1b). As to the invasive status, herbs, trees and shrubs were the most frequent life-forms among casual and naturalized species (Fig. 1b). Species listed as invasive were mostly herbs, grasses and trees (Table S2 in ESM). Most alien species $(81.1 \%)$, regardless of their invasive status, were found to be perennials, while annuals and biennials accounted for 18.7 and $0.2 \%$ respectively (Fig. 1c). Only two biennial species (Cynoglossum amabile and Cynoglossum zeylanicum) were listed in the alien flora of PRVI and both are naturalized species.

\section{Reproductive strategies}

The majority (77.8\%) of the alien plant species in PRVI are hermaphrodites with capability for outcrossing and mixed breeding system. The number of species rely almost exclusively on selfing (i.e., apomixes and autonomous self-pollination) is very low (Fig. 2a). For most casual (248 species), naturalized (346 species) and invasive species (107 species), pollination is primarily mediated by animals and to a lesser degree by wind (Fig. 2b). This result suggests that most species, regardless of their invasion status, require a pollen vector to ensure pollination and seed-set. Propagule dispersion for most species (casual: 170 species, naturalized: 274 species and invasive: 117 species) was primarily unspecialized followed by wind-dispersal and animal-dispersal (Fig. 2c).

Invasion history and geographic distribution

Our data suggest an accelerated increment in the cumulative number of alien plant species since 1875 . Fifty-one percent of all alien species (534 species) were first recorded between 1875 and 1924, while 362 species (34.5\%) after 1925 (Fig. 3). Seventy-one percent of the species considered invasive on these islands (121 species) have a long residence time as they were introduced between 1875 and 1925 (Table
S2 in ESM). Regarding the type of introduction, we detected that $32.3 \%$ (333 species) of all alien species were intentionally planted into wild ecosystems, $58.7 \%$ (606 species) have escaped from cultivation and $6.9 \%$ (71 species) are the result of unintentional introductions (i.e., stowaway or contaminants). Our analysis also shows that the majority of the alien species $(50.8 \%)$ were deliberately introduced as ornamentals (although not always exclusively). Other species were introduced for agriculture, forage, fodder and timber production. As to the geographical distribution, the majority of the alien species in PRVI are native to continental America (49.9\% including North, Central, and South America), followed by Asia (36.7\%), Africa $(22.5 \%)$, Austro-Pacific Islands $(15 \%)$, other islands of the West Indies $(6.7 \%)$ and Europe $(6.4 \%)$.

\section{Habitat preferences}

Casual, naturalized and invasive species occurred in all four habitats (i.e., agricultural, ruderal, seminatural and mature forest; Table 1) as defined in this study (Fig. 4a). Ruderal habitats (i.e., human-made habitats, excluding agricultural) host the highest number of casual, naturalized and invasive species, followed by semi-natural and by agricultural habitats (Fig. 4a). Mature forests contain a considerably lower number of casual (1 species), naturalized (12 species) and invasive species (18 species) when compared to the other three habitats. Species invading mature forests in PRVI include Crassocephalum crepidioides, Dissotis rotundifolia, Oeceoclades maculata, Scheffera actinophylla, Syngonium podophyllum and Syzygium jambos (Table S2 in ESM).

Regarding the occurrence of alien plants in the six different climatic life-zones described for PRVI (Table 1), we found that $58 \%$ of the alien species only occur in one life-zone, $25 \%$ occur in two life zones, and a less than $17 \%$ occur in three or more lifezones. Casual, naturalized and invasive species occur in all life zones, but were considerably more frequent in moist and dry forests (Fig. 4b).

Parameters determining naturalization and invasion success

The best-fit model for the naturalization of alien plants in PRVI includes five parameters (Table 3). This 
Fig. 2 Classification of the alien flora of Puerto Rico and the Virgin Island considering: a breeding system, b pollination type and $\mathbf{c}$ dispersal mode
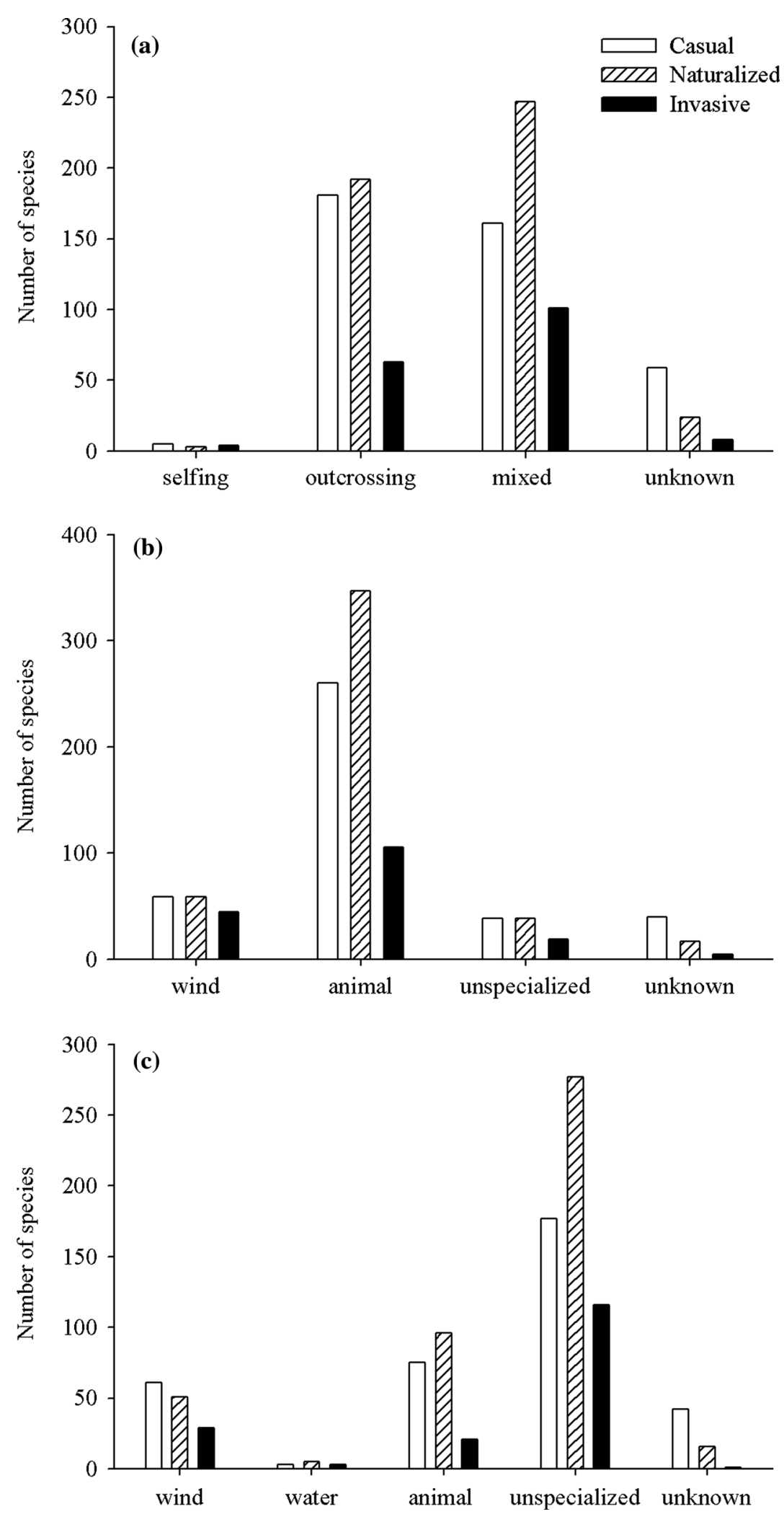
Fig. 3 Temporal patterns of introduction of alien plants species into Puerto Rico and the Virgin Islands

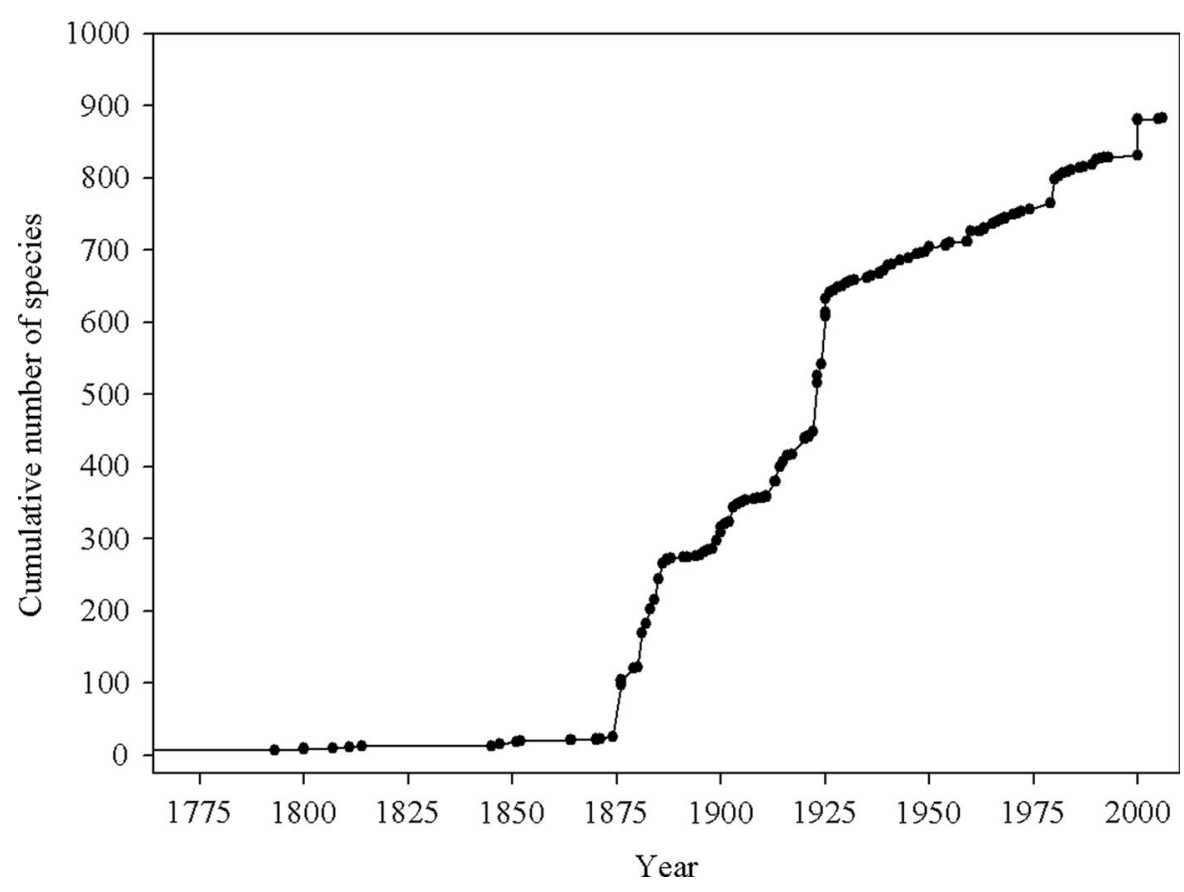

model was significantly different from the interceptonly model (likelihood ratio $\chi^{2}=95.37$; df $=5$; $P=0.001)$ and there was no evidence for a lack of fit (Pearson $\chi^{2}=156.40 ; \quad \mathrm{df}=492 ; \quad P=0.651$; $41.1 \%$ of the uncertainty explained by the model). This model showed that alien species were more likely to become naturalized if they grew in semi-natural habitats, had large native distribution ranges, had a long residence time in PRVI, were introduced for horticulture and had a mixed breeding system. These parameters are arranged in order of importance according to the odds ratios (Table 3).

For the transition from naturalization to invasion, we found that the best-fit model included eight parameters. This model was significantly different from the intercept-only model (Likelihood ratio $\chi^{2}=76.64 ; \mathrm{df}=8 ; P=0.001 ;$ Table 3 ) and there was no evidence for a lack of fit (Pearson $\chi^{2}=107.41 ;$ df $=404 ; P=0.752 ; 44.6 \%$ of the uncertainty explained by the model; Table 3 ). Our model suggests that naturalized species were more likely to become invasive if they were introduced for horticulture, behaved as weeds, occurred in different life-zones, had a mixed breeding system, hermaphrodite flowers, thrived in ruderal habitats, showed vegetative growth and had small seeds $(<2 \mathrm{~mm})$. These parameters are again arranged in order of importance according to the odds ratios (Table 3).

\section{Discussion}

The 1,032 species of alien plants reported for PRVI represent about one-third of total plant diversity on these islands. This proportion is relatively high when compared to other islands of the Greater Antilles. For instance, alien plant species represent about $12 \%$ of the total plant diversity in Cuba, $18.4 \%$ in Hispaniola and $21.4 \%$ in Jamaica (Acevedo-Rodríguez and Strong 2012; González et al. 2012). These differences are even more noteworthy in PRVI as they are the smallest land mass within the Greater Antilles.

In general, the origin and quantity of alien plants in PRVI may be explained by historical and ecological (but not exclusively) factors. First, the historic role of Puerto Rico as a port of call for Europe-American trading routes during the colonization expansion (between $1500 \mathrm{~s}$ and $1890 \mathrm{~s}$; Dietz 1986) facilitated the introduction of numerous alien species, mostly from continental America but also from Africa, Asia, and Europe. Second, the extensive rates of humanmediated disturbance to which natural ecosystems in PRVI have been subjected. Previous studies have 
Fig. 4 Classification of the alien flora of Puerto Rico and the Virgin Islands considering: a habitat strategy and $\mathbf{b}$ its occurrence in different life zones. Note that some species can occur in more than one category

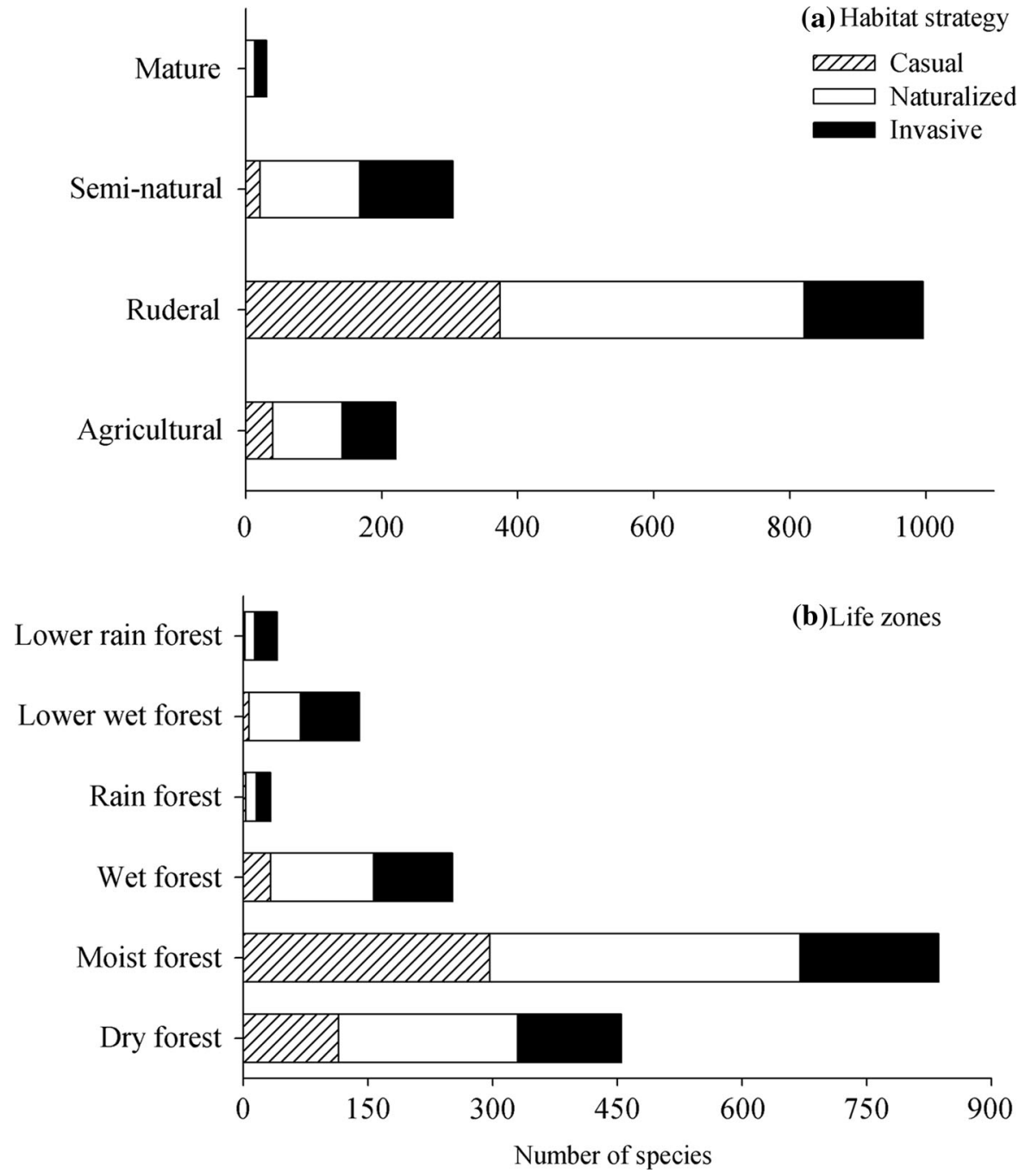

suggested that alien plants are most likely to become established in disturbed habitats rather than in pristine habitats (Sher and Hyatt 1999; Davis et al. 2000). In the case of PRVI, factors such as land-use change, high human population densities and high urban development have induced some of the major alterations in the landscape creating a vast number of open and degraded areas. These areas are characterized by harsh environmental conditions (i.e., high temperatures, low humidity, highly compacted soils), which may be preventing the colonization by native pioneers (Birdsey and Weaver 1987; Lugo 2004). Additionally, high disturbance rates and human activities impose higher propagule pressures and consequently facilitating colonization and invasion processes (Rejmánek
2000; Pyšek and Richardson 2006; Richardson and Pyšek 2012). In fact, early successional stages in abandoned and degraded fields in Puerto Rico are mostly dominated by alien plant species (Lugo 2004).

The alien flora in PRVI is very diverse and includes a wide range of taxonomic groups. Poaceae and Fabaceae are the families with the highest numbers of naturalized and invasive species, a fact that is not surprising since these two families are among the more diverse plant families of the world as well as among other Caribbean floras (Acevedo-Rodríguez and Strong 2012). In PRVI, most of the Poaceae species listed as naturalized and invasive come from abandoned pastures where they were intentionally introduced to support cattle activities (Williams and 
Table 3 Parameters included in the best-fit models explaining the successful probability of alien plant species of becoming naturalized and invasive in Puerto Rico and the Virgin Islands

\begin{tabular}{|c|c|c|c|c|}
\hline Parameters & Estimates & SE & $P$ & $\begin{array}{l}\text { Odds } \\
\text { ratios }\end{array}$ \\
\hline \multicolumn{5}{|c|}{ Transition from casual to naturalized } \\
\hline Intercept & 6.087 & 5.054 & 0.029 & \\
\hline Year of introduction & -0.017 & 0.325 & 0.001 & 0.983 \\
\hline $\begin{array}{l}\text { Introduced for } \\
\text { horticulture }\end{array}$ & 0.598 & 0.275 & 0.003 & 1.819 \\
\hline Native range & 1.279 & 0.354 & 0.014 & 3.592 \\
\hline $\begin{array}{l}\text { Habitat strategy (semi- } \\
\text { natural) }\end{array}$ & 1.868 & 0.811 & 0.001 & 6.478 \\
\hline $\begin{array}{l}\text { Breeding system } \\
\text { (mixed) }\end{array}$ & 0.323 & 0.191 & 0.002 & 1.382 \\
\hline \multicolumn{5}{|c|}{ Transition from naturalized to invasive } \\
\hline Intercept & 32.472 & 3.743 & $<0.001$ & \\
\hline $\begin{array}{l}\text { Introduced for } \\
\text { horticulture }\end{array}$ & 2.797 & 0.798 & $<0.001$ & 16.402 \\
\hline Life zones incidence & 1.048 & 0.537 & $<0.001$ & 2.852 \\
\hline Economic weed & 1.217 & 0.674 & 0.008 & 3.375 \\
\hline $\begin{array}{l}\text { Habitat strategy } \\
\text { (ruderal) }\end{array}$ & 0.830 & 0.278 & 0.002 & 2.292 \\
\hline $\begin{array}{l}\text { Reproduction type } \\
\text { (hermaphrodite) }\end{array}$ & 1.106 & 0.399 & 0.005 & 3.021 \\
\hline $\begin{array}{l}\text { Breeding system } \\
\text { (mixed) }\end{array}$ & 1.081 & 0.415 & 0.001 & 2.947 \\
\hline Seed size $(>5 \mathrm{~mm})$ & -0.532 & 0.268 & 0.041 & 0.587 \\
\hline $\begin{array}{l}\text { Vegetative } \\
\text { propagation }\end{array}$ & 0.886 & 0.255 & $<0.001$ & 2.423 \\
\hline
\end{tabular}

Baruch 2000). Similarly, most of the Fabaceae species comes from active and abandoned agro-forestry systems where they were primarily introduced to be used as nitrogen-fixers, fodder and ornamentals (Daehler 1998; Richardson and Rejmánek 2011).

The life forms of the alien flora in PRVI are very diverse and are characterized by a high proportion of perennial herbs and grasses. Herbs and grasses account for $41 \%$ of all alien species and for $52 \%$ of all species listed as invasive on these islands. This pattern of dominance of herbaceous growth forms has been observed in other alien floras in the Caribbean as well as in other tropical and extratropical islands (Lloret et al. 2005; Denslow et al. 2009; Arianoutsou et al. 2010; González et al. 2012). One interesting result of this study is the high proportion of alien trees and shrubs occurring in
PRVI. Together these life-forms account for $42.4 \%$ of all alien species and for $28.2 \%$ of all species listed as invasive. Until recently, alien trees and shrubs have not been perceived as problematic species mainly because most of them were introduced to provide some type of economic-services (i.e., forestry and ornamentals). However, recent studies have shown that alien trees and shrubs are among the most conspicuous and damaging invasive species worldwide (Pyšek et al. 2009, Richardson and Rejmánek 2011). In the case of Puerto Rico, a contrasting opinion presents some alien tree species (i.e., Spathodea campanulata and Erythrina poepigiana) as pioneers featuring important ecological functions restoring forest cover and biodiversity at highly degraded sites (Lugo 2004). In PRVI some of the most widespread and damaging invasive trees and shrubs are Albizia lebbeck, Leucaena leucocephala, Pinus caribaea, Spathodea campanulata, Syzygium jambos, Tabebuia rosea and Terminalia catappa. At present, none of these species are being controlled or have a mitigation or management plan for PRVI.

Parameters determining naturalization and invasion success

Parameters related to invasion history, habitat preferences and species biological traits were found to influence the probability of alien species to become naturalized and invasive in PRVI. Our data also showed that most parameters influencing the probability of becoming naturalized are different from those influencing the probability of becoming invasive. Similar patterns have been reported for tropical and extra-tropical alien floras where different sets of parameters are associated with naturalization or invasion success (Lloret et al. 2005, Pyšek and Richardson 2007; Milbau and Stout 2008; Dawson et al. 2009; Pyšek et al. 2012). For PRVI, we found a positive correlation between the year of introduction in the wild and the likelihood of becoming naturalized. The likelihood of alien species of becoming naturalized increases with the residence time because the longer a species is present in a specific region, the more propagules it is able to produce and disperse (Rejmánek et al. 2005; Richardson and Pyšek 2006; Pyšek et al. 2011). In addition, the likelihood for evolutionary adjustments (essential for successful establishment 
in highly stochastic environments such as humandisturbed landscapes) may increase with residence time (Mack et al. 2000).

Introduction for horticultural purposes is a parameter found to be important for both naturalization and invasion processes. This parameter is associated with repeated introductions and secondary release of popular species which are processes that may increase the influx of alien propagules and the chances of becoming naturalized and invasive (Mack and Lonsdale 2001; Reichard and White 2001; Milbau and Stout 2008; Pemberton and Liu 2009). For instance, $74 \%$ of the species listed as weeds in New Zealand originated as ornamentals and most of the worst environmental weeds in Hawaii were originally horticultural introductions (Buddenhagen et al. 1998; Daehler and Carino 1999). In PRVI, our data show that more than half of alien species have been intentionally introduced for horticulture. Under the current scenario of economic globalization, the dispersal of cultivated plants is promoted and easily achieved even from remote locations. Prevailing economic development in PRVI together with dynamic import markets, high population densities and high urban development, are factors facilitating the influx of alien species, increasing propagule pressure and lastly increasing the likelihood of becoming naturalized or invasive (Denslow et al. 2009; Kueffer et al. 2010).

Our results also show that the probability of alien species of becoming naturalized was positively correlated with the size of their native distribution range. Similar results have been found in North America, Central Europe and South Africa where many of the naturalized species have large natural distribution ranges (Rejmánek 1996; Thuiller et al. 2005; Cadotte et al. 2006; Pyšek et al. 2009). This correlation may respond to the fact that species with large distribution ranges may have tolerance to a wide range of environmental conditions, use a broad spectrum of resources and resist a large number of potential enemies (Pyšek and Richardson 2006).

Among the reproductive traits, hermaphroditism and mixed breeding system were most significant in increasing the likelihood of an alien species of becoming naturalized and invasive. In new habitats where pollen vectors can be limited or absent, facultative selfing could be crucial for the successful invasion of insular ecosystems as they are often characterized by depauperate pollinator communities
(Barrett et al. 1996; Lloret et al. 2005; Denslow et al. 2009). In this context, while selfing may ensure reproductive success when pollen vectors are limited, outcrossing may enhance genetic variability and thus increase the probability of adaptation to new habitats (Milbau and Stout 2008).

Regarding the environmental parameters, we found that alien species are more likely to become invasive if they grow in ruderal areas and produce small seeds (Kolar and Lodge 2001). Species with small seeds are often light-demanding and require bare substrates in order to germinate and become established (Pyšek and Richardson 2007). Species with small seeds are commonly associated with disturbed areas and high seed output, that can be easily dispersed by wind or water and can remain viable in the soil for long periods (Thompson et al. 1993). In PRVI, these two traits appear to correlate with disturbances and human activities Alternatively, studies addressing the effect of seed size and invasion success do not entirely support our findings as much variation is shown in their results (Lloret et al. 2005; Cadotte et al. 2006; Dawson et al. 2009).

Overall, our results suggest that particular trait combinations linked to the naturalization and invasion success of alien species are not universal and their relevance may vary among different habitats and geographical conditions as well throughout the spreading, colonization and invasion processes (Mack et al. 2000; Rejmánek 2000; Küster et al. 2008; Pyšek et al. 2009). In PRVI there is a lack of effective policies and protocols to prevent the introduction of alien plants and to control those that are already invasive. Our study should allow managers and lawmakers to target potentially invasive species before they start to exert impact on ecosystems and economies on these islands. Even when the ability to accurately predict species invasiveness will not be accomplished by a single study, the results presented here could be a starting point.

Acknowledgments We thank M. T. Strong and J. Knight for reviewing earlier versions of the manuscript and D. AnglésAlcázar for valuable programming advice. This research was supported by grants from the Smithsonian National Museum of Natural History and the US Department of Agriculture through The National Invasive Species Council.

Open Access This article is distributed under the terms of the Creative Commons Attribution License which permits any use, distribution, and reproduction in any medium, provided the original author(s) and the source are credited. 


\section{References}

Acevedo-Rodríguez P (1996) Flora of St. John, US Virgin Islands. Mem New York Bot Gard, New York

Acevedo-Rodríguez P (2005) Vines and climbing plants of Puerto Rico and the Virgin Islands. Contrib United States Nat Herb 51:1-483

Acevedo-Rodríguez P, Strong MT (2005) Monocotyledons and gymnosperms of Puerto Rico and the Virgin Islands. Contrib United States Nat Herb 52:1-415

Acevedo-Rodríguez P, Strong MT (2012) Catalogue of seed plants of the West Indies. Smithsonian Contributions to Botany, No. 98. Smithsonian Institution Scholarly Press, Washington DC

Aide TM, Zimmerman JK, Herrera L, Rosario M, Serrano M (1995) Forest recovery in abandoned tropical pastures in Puerto Rico. Forest Ecol Manag 77:77-86

Arianoutsou M, Bazos I, Delipetrou P, Kokkoris Y (2010) The alien flora of Greece: taxonomy, life traits and habitat preferences. Biol Invasions 12:3525-3549

Axelrod F (2011) A systematic vademecum to the vascular plants of Puerto Rico. BRIT Press, Fort Worth

Barrett SC, Emerson B, Mallet J (1996) The reproductive biology and genetics of island plants. Philos Trans Roy Soc Series B 351:725-733

Bello D (1881) Apuntes para la flora de Puerto Rico. Anales Sociedad Española de Historia Natural 10:231-304

Bello D (1883) Apuntes para la flora de Puerto Rico II. Anales Sociedad Española de Historia Natural 12:103-130

Birdsey RA, Weaver PL (1987) Forest area trends in Puerto Rico. US Department of Agriculture, Forest Service, Research Note, SO-331. International Institute of Tropical Forestry, Puerto Rico

Britton NL, Wilson P (1923) Scientific survey of Porto Rico and the Virgin Islands Vol. 5: botany of Puerto Rico and the Virgin Islands. New York Academy of Science, USA

Britton NL, Wilson P (1926) Scientific survey of Porto Rico and the Virgin Islands Vol. 6: botany of Puerto Rico and the Virgin Islands. New York Academy of Science, USA

Buddenhagen CE, Timmins SM, Owen SJ, Champion PD, Nelson W, Reid VA (1998) An overview of weed impacts and trends. In: Owen SJ (ed) Conservation strategic plan for managing invasive weeds. Department of Conservation, Wellington, pp 11-21

Cadotte MW, Murray BR, Lovett-Doust J (2006) Ecological patterns and biological invasions: using regional species inventories in macroecology. Biol Invasions 8: 809-821

Catford JA, Jansson R, Nilsson C (2009) Reducing redundancy in invasion ecology by integrating hypotheses into a single theoretical framework. Divers Distrib 15:22-40

D’Antonio CM, Dudley TL (1995) Biological invasions as agents of change on islands versus mainlands. In: Vitousek PM, Loope LL, Adsersen H (eds) Islands-biological diversity and ecosystem function. Springer, Berlin, pp 103-121

D'Antonio CM, Jackson NE, Horvitz CC, Hedberg R (2004) Invasive plants in wildland ecosystems: merging the study of invasion processes with management needs. Front Ecol Env 2:513-521
Daehler CC (1998) The taxonomic distribution of invasive angiosperm plants: ecological insights and comparison to agricultural weeds. Biol Conserv 84:167-180

Daehler CC (2003) Performance comparisons of co-occurring native and alien invasive plants: implications for conservation and restoration. Annu Rev Ecol Evol Syst 1:183-211

Daehler CC, Carino DA (1999) Threats of invasive plants to the conservation of biodiversity. In: Chou $\mathrm{CH}$, Waller GR, Reinhardt C (eds) Biodiversity and allelopathy: from organisms to ecosystems in the Pacific. Academica Sinica, Taipei, pp 21-27

Daly C, Helmer EH, Quiñones M (2003) Mapping the climate of Puerto Rico, Vieques and Culebra. Int $\mathrm{J}$ Climatol 23:1359-1381

Davis MA, Grime JP, Thompson K (2000) Fluctuating resources in plant communities: a general theory of invasibility. J Ecol 88:528-534

Dawson W, Burslem DFRP, Hulme PE (2009) Factors explaining alien plant invasion success in a tropical ecosystem differ at each stage of invasion. J Ecol 97:657-665

Denslow JS (2003) Weeds in paradise: thoughts on the invasibility of tropical islands. Ann Missouri Bot Gard 90:119-127

Denslow JS, Space JC, Thomas PA (2009) Invasive exotic plants in tropical Pacific Islands: patterns of diversity. Biotropica 41:62-170

Dietz JL (1986) Economic history of Puerto Rico: institutional change and capitalist development. Princeton University Press, USA

Eggers HFA (1876) St. Croix's flora. Vid-Medd Kjobenhavn, Copenhagen

Eggers HFA (1879) The flora of St. Croix and the Virgin Islands. Bull United States Nat Mus 13:1-133

Ewel JJ, Whitmore JL (1973) Ecological life zones of Puerto Rico and US Virgin Islands. Forest Service Research Papers ITF-18. Institute of Tropical Forestry, Puerto Rico

Fernández de Oviedo G (1535) Historia General de Las Indias: Islas y Tierra Firme. Juan Cromberger, Sevilla, Spain

Franco PA, Weaver PL, Eggen-McIntosh S (1997) Forest resources of Puerto Rico. Resource Bulletin SRS-22. U.S. Forest Service, Southern Research Station. Asheville, North Carolina

García-Molinari O (1952) Pasture and forage grass species and their ecology in the Caribbean area. Proceedings VI International Grassland Congress Grass 11:1440-1445

González LR, Rankin R, Palmarola A (2012) Plantas invasoras en Cuba. Bissea 6:1-140

Heatwole H, Levins R, Byer M (1981) Biogeography of the Puerto Rican Bank. Atoll Res Bull 251:1-62

Higgins SI, Richardson DM (1999) Predicting plant migration rates in a changing world: the role of long-distance dispersal. Am Nat 153:464-475

Kairo M, Ali B, Cheesman O, Haysom K, Murphy S (2003) Invasive species threats in the Caribbean region. Report to The nature conservancy. CAB International, Egham

Khuroo AA, Reshi ZA, Malik AH, Weber E, Rashid I, Dar GH (2012) Alien flora of India: taxonomic composition, invasion status and biogeographic affiliations. Biol Invasions 14:99-113

Kolar CS, Lodge DM (2001) Progress in invasion biology: predicting invaders. Trends Ecol Evol 16:199-204 
Kueffer C, Daehler CC, Torres-Satana CW, Lavergne C, Meyer JY, Otto R, Silva L (2010) A global comparison of plant invasions on oceanic islands. Perspect Plant Ecol Syst 12:145-161

Küster EC, Kühn I, Bruelheide H, Klotz S (2008) Trait interactions help explain plant invasion success in the German flora. J Ecol 96:860-868

Levine JM, Vilà M, D’Antonio CM, Dukes JS, Grigulis K, Lovorel S (2003) Mechanisms underlying the impacts of exotic plant invasions. Proc R Soc London B 270:775-781

Liogier AH (1985-1997) Descriptive flora of Puerto Rico and adjacent islands. Spermatophyta 1-5. Editorial de la Universidad de Puerto Rico, Puerto Rico

Liogier AH, Martorell LF (1982) Flora of Puerto Rico and adjacent islands: a systematic synopsis. Universidad de Puerto Rico, Puerto Rico

Lloret F, Médail F, Brundu G, Camarda I, Moragues E, Rita J, Lambdon P, Hulme PE (2005) Species attributes and invasion success by alien plants on Mediterranean islands. J Ecol 93:512-520

López del Mar T, Aide TM, Thomlinson JR (2001) Urban expansion and the loss of prime agricultural lands in Puerto Rico. Ambio 30:49-54

Lugo AE (2004) The outcome of alien tree invasions in Puerto Rico. Front Ecol Env 2:265-273

Mack RN, Lonsdale WM (2001) Humans as global plant dispersers: getting more than we bargained for. Bioscience 51:95-102

Mack RN, Simberloff D, Lonsdale WM, Evans H, Clout M, Bazzaz FA (2000) Biotic invasions: causes, epidemiology, global consequences, and control. Ecol Appl 10:689-710

Más EG, Lugo-Torres ML (2013) Common weeds in Puerto Rico and U.S. Virgin Islands. University of Puerto Rico and the USDA Natural Resources Conservation Service, Puerto Rico

Maunder M, Leiva A, Santiago-Valentín E, Stevenson DW, Acevedo-Rodríguez P, Meerow AW, Mejía M, Clubbe J, Francisco-Ortega J (2008) Plant conservation in the Caribbean Island biodiversity hotspot. Bot Rev 74:197-207

Menard S (2002) Applied logistic regression analysis, 2nd edn. Sage Publications, California

Milbau A, Stout JC (2008) Factors associated with plants transitioning from casual, to naturalized, to invasive. Conserv Biol 22:308-317

Mittermeier RA, Myers N, Thomsen JB, Da Fonseca GAB, Olivieri S (1998) Biodiversity hotspots and major tropical wilderness areas: approaches to setting conservation priorities. Conserv Biol 12:516-520

Myers N, Mittermeier RA, Mittermeier CG, da Fonseca GAB, Kent J (2000) Biodiversity hotspots for conservation priorities. Nature 403:853-858

Pemberton RW, Liu H (2009) Marketing time predicts naturalization of horticultural plants. Ecology 90:69-80

Pyšek P, Richardson DM (2006) The biogeography of naturalization in alien plants. J Biogeogr 33:2040-2050

Pyšek P, Richardson DM (2007) Traits associated with invasiveness in alien plants: where do we stand? In: Nentwig W (ed) Biological invasions, ecological studies, vol 193. Springer, Berlin, pp 97-125

Pyšek P, Richardson DM (2010) Invasive species, environmental change and management, and health. Annu Rev Env Resour 35:25-55
Pyšek P, Richardson DM, Rejmánek M, Webster GL, Williamson M, Kirschner J (2004) Alien plants in checklists and floras: towards better communication between taxonomists and ecologists. Taxon 53:131-143

Pyšek P, Křivánek M, Jarošík V (2009) Planting intensity, residence time, and species traits determine invasion success of alien woody species. Ecology 90:2734-2744

Pyšek P, Jarošik V, Pergl J (2011) Alien plants introduced by different pathways differ in invasion success: unintentional introductions as a threat to natural areas. PLoS ONE 6:e24890

Pyšek P, Jarošík V, Hulme PE, Pergl J, Hejda M, Schaffner U, Vilà M (2012) A global assessment of invasive plant impacts on resident species, communities and ecosystems: the interaction of impact measures, invading species traits and environment. Glob Change Biol 18:1725-1737

Reichard SH, White P (2001) Horticulture as a pathway of invasive plant introductions in the United States. Bioscience 51:103-113

Rejmánek M (1996) Species richness and resistance to invasions. In: Orians G, Dirzo R, Cushman JH (eds) Biodiversity and ecosystem processes in tropical forests. Springer, Berlin, pp 153-172

Rejmánek M (2000) Invasive plants: approaches and predictions. Austral Ecol 25:497-506

Rejmánek M, Richardson DM, Pyšek P (2005) Plant invasions and invasibility of plant communities. In: van der Maarel E (ed) Vegetation ecology. Blackwell Science, Oxford, pp 332-355

Richardson DM, Pyšek P (2006) Plant invasions: merging the concepts of species invasiveness and community invasibility. Prog Phys Geogr 30:409-431

Richardson DM, Pyšek P (2012) Naturalization of introduced plants: ecological drivers of biogeographical patterns. New Phytol 196:383-396

Richardson DM, Rejmánek M (2011) Trees and shrubs as invasive alien species: a global review. Divers Distrib 17:788-809

Richardson DM, Pyšek P, Rejmánek M, Barbour MG, Panetta FD, West CJ (2000) Naturalization and invasion of alien plants: concepts and definitions. Divers Distrib 6:93-107

Sax DF, Gaines SD, Brown JH (2002) Species invasions exceed extinctions on islands worldwide: a comparative study of plants and birds. Am Nat 160:766-783

Sher AA, Hyatt LA (1999) The disturbed resource-flux invasion matrix: a new framework for patterns of plant invasion. Biol Invasions 1:107-114

Simberloff D (1995) Why do introduced species appear to devastate islands more than mainland areas? Pac Sci 49:87-97

Simberloff D (2000) Extinction-proneness of island speciescauses and management implications. Raffles Bull Zool 48:1-9

Stahl A (1883-1888) Estudios sobre la flora de Puerto Rico 1-6. El Asimilista (Volumen 1) and De González and Co. (Volums 2-6), San Juan, Puerto Rico

Thompson K, Band SR, Hodgson JG (1993) Seed size and shape predict persistence in soil. Funct Ecol 7:236-241

Thuiller W, Richardson DM, Pyšek P, Midgley GF, Hughes GO, Rouget M (2005) Niche-based modelling as a tool for predicting the risk of alien plant invasions at a global scale. Glob Change Biol 11:2234-2250 
Urban I (1898-1928) Symbolae Antillanae: Fundamenta florae Indiae Occidentalis 1-9. Frates Borntraeger, Berlin

Weber E (2003) Invasive plant species of the world. A reference guide to environmental weeds. CABI Publishing, Wallingford
Williams DG, Baruch Z (2000) African grass invasion in the Americas: ecosystem consequences and the role of ecophysiology. Biol Invasions 2:123-140 